\title{
MODEL CORPORATE SOCIAL RESPONSIBILITY DALAM PROGRAM PEMBERDAYAAN PETANI HORTIKULTURA
}

\author{
Etty Soesilowati, Dyah Rini Indriyanti, dan Widiyanto \\ Fakultas Ekonomi Universitas Negeri Semarang \\ Kampus Sekaran Gunungpati Semarang 50229 Jawa Tengah Telepon 024-70778922
}

Diterima 12 September 2010/Disetujui 15 April 2011

\begin{abstract}
This research aimed to analyze the model of empowering dry land farmers in Central Java, the actors involved, the constraints faced, the impact and level of effectiveness. The study used two approaches: qualitative and quantitative approaches. In the qualitative approach, data were analyzed by using an interactive model. While the quantitative approach carried out by using the cost and benefit analysis. In the qualitative approach, data were analyzed by using an interactive model. While the quantitative approach conducted by using the cost and benefit analysis. The results showed that CSR was done through the assistance of technical consultants by applying concept "one product one village"; institutions involved include SOEs (State-Owned Enterprises), the Provincial Government, Local Government, Village Government, Private Companies and Community. The external constraints that happen came from cultural differences of government and private organizations as well as the existence of unpredictable extreme weather. Meanwhile the internal constraints derived from the knowledge level of farmers; ROI calculation result showed that the planting of horticulture commodities was profitable.
\end{abstract}

Keywords: corporate social responsibility, hortikultura farmer empowerment, dry land farmer, social preparing

\begin{abstract}
Abstrak: Penelitian bertujuan mengkaji model pemberdayaan petani hortikultura di Jawa Tengah, aktor yang terlibat, kendala yang dihadapi, dampak yang ditimbulkan serta tingkat efektivitasnya. Penelitian menggunakan dua pendekatan, yaitu pendekatan kualitatif serta kuantitatif. Pada pendekatan kualitatif, data dianalisa dengan menggunakan model interaktif. Sedangkan pendekatan kuantitatif dilakukan dengan menggunakan cost $\mathcal{E}$ benefit analisis. Hasil penelitian menunjukan bahwa CSR dilakukan melalui pendampingan konsultan teknis dengan menerapkan konsep "one product one village"; institusi yang terlibat meliputi BUMN, Pemerintah Provinsi, Pemerintah Daerah, Pemerintahan Desa, Swasta maupun masyarakat; kendala eksternal yang terjadi bersumber dari perbedaan kultur organisasi pemerintah dan swasta serta keberadaan cuaca ekstrem, sedangkan kendala internal bersumber dari tingkat pengetahuan petani; hasil perhitungan Benefit Cost Ratio, Return On Investment, Payback Ratio menunjukkan bahwa penanaman komoditas holtikultura menguntungkan.
\end{abstract}

Kata kunci: CSR, pemberdayaan petani hortikultura, petani lahan kering, social preparing

\section{PENDAHULUAN}

Sejak lama dunia usaha percaya bahwa satusatunya tanggungjawab mereka adalah membuat keuntungan bagi pemodalnya. Kelompok yang menolak mengajukan argumen bahwa perusahaan adalah organisasi pencari laba dan bukan kumpulan orang seperti halnya organisasi sosial. Kelompok yang mendukung berpendapat bahwa perusahaan tidak dapat dipisahkan dari masyarakat sekitarnya karena: pertama, 
masyarakat adalah sumberdaya yang potensial dan direproduksi oleh perusahaan. Tanpa dukungan masyarakat perusahaan mustahil memiliki pelanggan, pegawai dan sumber-sumber produksi lainnya; kedua, meskipun perusahaan telah membayar pajak kepada negara tidak berarti telah menghilangkan tanggungjawabnya terhadap kesejahteraan publik. Karenanya perusahaan haruslah mengadopsi kenyataan bahwa ada dua bentuk perijinan yang harus dipatuhi agar dapat beroperasi dengan aman, yaitu ijin legal dari pemerintah dan ijin sosial dari masyarakat dengan melakukan kegiatan sosial (CSR)

Corporate Social Responsibility (CSR) sangat relevan diterapkan oleh dunia usaha di Indonesia karena selain kebijakan sosial dan kebijakan kesejahteraan di Indonesia cenderung bernuansa residual dan parsial, tidak melembaga dan terintegrasi dengan sistem perpajakan seperti halnya di negara-negara yang menganut welfare state, mayoritas masyarakat Indonesia masih hidup dalam kondisi serba kekurangan. Disisi lain mind set pemerintah sebagai penyelenggara negara lebih mengutamakan penyediaan lapangan pekerjaaan di sektor industri/pabrikpabrik, mengabaikan produk primer (pertanian). Kemampuan petani tidak diurus dan secara frontal di era perdagangan bebas ini dihadapkan dengan petani manca negara yang produknya lebih bagus dan murah. Kurikulum pendidikan pertanian sendiri tidak memberikan kompetensi alumni, sangat ketinggalan dan tidak mengakomodasi kebutuhan pertanian global serta teknologi terkini. Saat ini petani tidak mendapatkan haknya untuk memperoleh pengetahuan dan informasi, pendidikan dan pelatihan yang mamadai, bibit, pupuk dan obat tanaman yang terjamin mutunya. Tidak ada pembangunan waduk baru pasca 1988 , sementara waduk lama mengalami sedimentasi.

Komoditi pangan kecuali beras yang diimpor "tidak seberapa", kebutuhan komoditi pangan kita diisi dengan produk impor, antara lain 75 persen kedelai, 50 persen gula, 50 persen jagung dan seterusnya. Tidak nampak petani pangan yang makmur. Beberapa pabrik menjadi besar dan makmur tetapi produsen bahan bakunya (petani) merana dan miskin tidak berkembang sehingga beberapa perusahaan mulai memenuhi kebutuhannya dengan mengimpor. Sementara pasar-pasar swalayan dan toko buah yang berkualitas memberi nilai tambah tinggi pada buah dan sayur impor.

Petani sebagai subyek dunia pertanian sejak dimulainya pembangunan pertanian di Indonesia dan di belahan dunia lainnya diera globalisasi tidak pernah menjadi aktor utama. Mereka lebih sebagai obyek penerima dan pelaksana kebijakan yang seringkali tidak menguntungkan. Situasi ini mengingatkan kita pada tahun 1960-an, dimana kita kekurangan pangan akibat situasi politik dan ledakan jumlah penduduk yang tak terkendali. Pembangunan pertanian saat itu dibangun dengan mengadopsi model yang sedang berkembang di berbagai belahan dunia, dimana model pertanian tradisional dianggap tidak layak karena yang dibutuhkan adalah ketersediaan pangan dalam jumlah yang besar dan waktu yang cepat.

Sejak saat itu terjadilah perubahan besarbesaran ditingkat petani dan lingkungannya, dimana petani yang tidak pernah menggunakan benih luar, pupuk kimia dan pestisida dipaksa menggunakannya. Dampak ini tentunya sangat luar biasa, antara lain pemerintah Indonesia dinyatakan swasembada beras, sehingga masyarakat Indonesia yang semula memiliki keanekaragaman pangan menjadi merubah pola makan utamanya menjadi beras. Penggunaan alat mekanisasi bahkan penggusuran dan hilangnya hak tanah akibat pembangunan waduk menyebabkan hilangnya akses ekonomi petani. Rata-rata kepemilikan lahan petani/ kepala di Jawa hanya 0,2 ha sehingga sangat sulit memenuhi kebutuhan hidup secara layak (Dinas Pertanian Tanaman Pangan, 2008)

Lebih lanjut, ketimpangan pembangunan pertanian ini adalah berpindahnya ketenagakerjaan dari pertanian ke industri. Fenomena perpindahan petani ke industri merubah pola kehidupan mereka dan wajah desa. Masyarakat desa kemudian pindah ke kota untuk mencari sumber kehidupan yang lebih baik. Kota menjadi padat sementara sarana dan prasarana kehidupan terbatas.

Banyak pendekatan dan strategi yang sudah dilakukan oleh berbagai pihak serta pemerintah untuk mendorong tumbuhnya sumber- 
sumber pendapatan keluarga petani di perdesaan tanpa harus merubah budaya kehidupan yang sudah dikenalnya. Strategi yang banyak dikembangkan mencakup 2 hal, yakni on farm dan off farm. Model on farm (dilahan pertanian) yang dikembangkan tidak harus kembali pada model tradisional, namun perlu disesuaikan dengan situasi lingkungan yang sudah berubah. Salah satunya yang perlu dikembangkan adalah model pertanian terpadu (sustainable agriculture) dimana cara ini memadukan beragam cara petani memiliki kesempatan memperoleh tambahan pendapatan dari berbagai sumber. Pertanian berkelanjutan adalah multikultur, menghargai keanekaragaman hayati, menghargai kearifan lokal, menggunakan teknologi tepat guna serta sesuai dengan budaya lokal, namun memiliki nilai tambah ekonomi yang tinggi.

Pertanian lahan kering yang tidak mendapat irigasi dan tak pernah tersentuh pembangunan pertanian menjadi prioritas karena banyak dijumpai di Jawa Tengah.

Tabel 1. Luas Lahan Kering di Jawa Tengah

\begin{tabular}{lrc}
\hline Luas lahan kering & $\mathbf{1 . 5 4 1 . 8 5 3}$ ha & $\mathbf{6 1 , 3 7 \%}$ \\
\hline Pekarangan & 575.916 ha & $22,92 \%$ \\
Tegal/kebun & 759.028 ha & $30,21 \%$ \\
Ladang/huma & 9.587 ha & $0,38 \%$ \\
Padang rumput & 2.662 ha & $0,11 \%$ \\
Rawa-rawa & 4.742 ha & $0,19 \%$ \\
Tambak & 35.728 ha & $1,42 \%$ \\
Kolam/Tebat/Empang & 2.385 ha & $0,09 \%$ \\
Lahan kering tidak & 4.896 ha & $0,19 \%$ \\
diusahakan sementara & & \\
Hutan rakyat & 69.735 ha & $2,78 \%$ \\
Hutan negara & 0 & 0 \\
Perkebunan & 77.174 ha & $3,07 \%$ \\
Lain-lain & 0 & 0 \\
\hline
\end{tabular}

Sumber: Pengelolaan Sumber Daya Alam Provinsi Jawa Tengah (2008)

Melihat kondisi di atas, Yayasan Obor tani melalui program CSR mencoba menawarkan konsep "one product one village" dengan tujuan memudahkan pengelolaan, penanganan hama tanaman, pemasaran produk dan efisiensi. Secara umum kegiatan CSR ini menggunakan strategi sebagai berikut: pertama, membuat ke- bun percontohan beberapa tanaman unggulan sekaligus difungsikan sebagai agrowisata dengan nama "Plantera Fruit"; kedua, menentukan prioritas jenis lahan dan komoditas yang cocok daerah sasaran; ketiga, diklat kader tani, dimana memberikan pembekalan ilmu dan profesionalisme petani dengan muatan 80 persen praktek disertai riset; keempat, pendirian sentra pemberdayaan tani di zona Sentra Pemberdayaan Tani (SPT). SPT berfungsi sebagai supplay center; training center (petani berlatih, petani bertanya, petani melihat contoh); research center; kelima, membangun infrastruktur di zona pertanian.

Dalam kerangka mewujudkan program "Mbalik Deso Mbangun Deso" serta melihat model yang telah dikembangkan Yabortan, provinsi Jawa Tengah berkeinginan membangun SPT di atas lahan kering di lokasi : pertama, Dusun Jumbleng, Desa Wonokerto, Kecamatan Bancak dengan komuditas buah naga jenis Red Dragon yang diperuntukan bagi 88 KK seluas 20 ha. dimana setiap peserta memiliki lahan $2.000 \mathrm{~m} 2=200$ pohon, sehingga total tanaman 17.600 pohon; kedua, Dusun Sukorejo, Kecamatan Musuk Kabupaten Boyolali dengan komoditas durian Montong yang diperuntukan bagi $94 \mathrm{KK}$ seluas 20 ha, dimana setiap petani memiliki lahan seluas $2.000 \mathrm{~m} 2=32$ pohon, sehingga secara keseluruhan berjumlah 3.125 pohon; ketiga, dusun Labuhan Kidul kecamatan Sluke kabupaten Rembang dengan komuditas mangga Arumanis dan Nam Dokmai diperuntukkan bagi 107 KK dimana 12 ha merupakan revitalisasi kebun yang sudah ada dan 9 ha baru. Setiap petani memiliki $2.000 \mathrm{~m} 2$ lahan = 32 pohon, sehingga secara keseluruhan terdapat 1.407 poho; keempat, Dusun Seboro Kecamatan Sadang Kabupaten Kebumen dengan komoditas lengkeng Itoh diperuntukkan bagi 104 KK seluas 20 ha. Setiap petani memiliki lahan seluas $2.000 \mathrm{~m} 3=40$ pohon, sehingga secara keseluruhan terdapat 4.000 pohon.

Adapun untuk mewujudkannya Pemprop. mencoba mengintegrasikannya beberapa program CSR BUMN. Untuk itulah penelitian ini dilakukan dalam kerangka mengkaji: pertama, mekanisme pengintegrasian kebijakan CSR oleh Pemprop Jateng; kedua, institusi dan aktor yang terlibat; ketiga, instrumen-instrumen kepengaturan yang digunakan; keempat, pendekatan- 
pendekatan yang dilakukan; kelima, dampak yang ditimbulkan dan kendala yang terjadi; keenam, serta tingkat efektivitasnya.

Tujuan dari penelitian ini adalah untuk memonitoring, mengevaluasi sejauhmana efektivitas kebijakan Pemerintah Provinsi Jawa Tengah dalam kaitannya program "Bali Deso Mbangun Deso" melalui pengintegrasian kegiatan corporate social responsibility Penelitian ini diharapkan bermanfaat tidak saja untuk meningkatkan kesejahteraan petani dan produktivitas lahan kering tetapi juga mengurangi ketergantungan akan produk impor, memupuk rasa tanggungjawab bersama antara pemerintah, swasta dan masyarakat serta jangka panjang mengurangi tingkat urbanisasi dan kemacetan kota.

Kajian Pustaka. Sejak dahulu para ahli ekonomi klasik dan non-klasik seperti Adam Smith, David Ricardo, TR. Malthus dan Mill telah mengemukakan beberapa teori pembangunan untuk menjawab bagaimana suatu bangsa dapat memperbaiki perekonomiannya. Adam Smith dalam bukunya "An Inquiry Into The Nature and Causes of The Wealth of Nation" mengemukakan bahwa faktor penduduk yang bertambah akan memperluas pasar dan mendorong spesialisasi. Dengan spesialisasi akan mendorong produktivitas dan perkembangan teknologi sehingga mempercepat kegiatan ekonomi. Pandangan Adam Smith sangat bertentangan dengan pandangan David Ricardo dan Malthus. David Ricardo dan Malthus lebih pesimis terhadap proses pembangunan dalam jangka panjang karena menurutnya perekonomian dalam jangka panjang akan mencapai "stationary state". Sementara perkembangan penduduk yang tidak terkendali akan menurunkan kembali ke tahapan pembangunan yang lebih rendah. Hal ini disebabkan karena berlakunya hukum kenaikan hasil yang semakin berkurang (the law of deminishing return). Artinya keterbatasan tanah disertai pertumbuhan penduduk berakibat menurunnya "marginal productivity". David Ricardo berpendapat bahwa peranan teknologi dan akumulasi modal akan mampu menghambat bekerjanya "the law of deminishing return". Sedangkan Malthus berpendapat bahwa kesejahteraan masyarakat tidak mungkin meningkat dan berkesinambungan tanpa pena- naman modal secara terus menerus. Sumber akumulasi modal adalah laba. Dalam bukunya "Principles of Political Economic", Malthus menekankan faktor-faktor non ekonomi seperti keamanan atas kekayaan, konstitusi, hukum yang baik memiliki pengaruh yang kuat. Malthus juga mengajukan beberapa saran bahwa melalui pertumbuhan berimbang di sektor pertanian dan sektor industri akan menyebabkan produktivitas meningkat. Sementara Mill mengemukakan bahwa pembangunan ekonomi suatu bangsa sangat tergantung pada perbaikan tingkat pengetahuan mayarakat dan upaya menghapus penghambat pembangunan seperti adat istiadat dan cara berpikir yang irasional. Faktor pendidikan memiliki fungsi mempertinggi pengetahuan teknik masyarakat dan ilmu pengetahuan umum.

Kondisi ini tentunya tidak dapat sepenuhnya diserahkan pada pemerintah sebagai representasi negara, tetapi memerlukan campurtangan seluruh elemen masyarakat. Hal ini amat relevan dengan pendapat Schumpeter yang menyatakan bahwa enterpreneur adalah golongan yang amat berperan dalam menumbuhkan perekonomian suatu bangsa. Mereka adalah pembaharu dan pencipta inovasi dalam bentuk: pertama, penciptaan barang baru; kedua, cara-cara baru; ketiga, pasar baru; keempat, sumber bahan mentah baru; serta kelima, sistem organisasi baru (Suryana, 2000: 56). Untuk itulah dalam UU Perseroan Terbatas, UU Investasi, dan UU Mineral dan Batubara telah ditetapkan bahwa setiap perusahaan yang bergerak di bidang sumberdaya alam wajib memberikan CSR kepada warga sekitar.

CSR adalah sebuah pendekatan dimana perusahaan mengintegrasikan kepedulian sosial dalam operasi bisnis mereka dan dalam interaksi mereka dengan para pemangku kepentingan (stakeholders) berdasarkan prinsip kesukarelaan dan kemitraan (Nuryana, 2005). Beberapa nama lain yang memiliki kemiripan atau bahkan sering diidentikkan dengan CSR antara lain amal perusahaan (Corporate Giving) Clarity), kedermawanan perusahaan (Corpotare Philanthropy) dan pengembangan masyarakat (Community Development). Ketiga nama itu bisa dilihat sebagai dimensi atau pendekatan CSR dalam konteks investasi sosial perusahan (Cor- 
porate Social Investment) yang didorong oleh spektrum motif "amal" hingga "pemberdayaan" (Asongu, J.J. http://www6.miami.edu/ ethics/pdf files/csr guide.pdf.)

Konsep CSR dikembangkan Archie B. Carrol dengan memberi justifikasi teoritis dan logis mengapa sebuah perusahaan perlu menerapkan CSR bagi masyarakat di sekitarnya. Dalam pandangan Carrol, CSR adalah puncak piramida yang erat terkait satu sama lain, meliputi: pertama, tanggungjawab ekonomis dengan kata kunci "make a profit", dimana motif utama perusahaan adalah menghasilkan laba. Laba adalah fondasi perusahaan. Perusahaan harus memiliki nilai tambah ekonomi sebagai prasyarat agar dapat terus hidup dan berkembang; kedua, tanggungjawab legal dengan kata kunci "obey the law", dimana perusahaan harus taat hukum dalam mencari laba; ketiga, tanggungjawab etis dengan kata kunci "be ethical", dimana perusahaan memiliki kewajiban untuk menjalankan praktek bisnis yang baik, benar, adil dan fair. Norma-norma masyarakat perlu menjadi rujukan bagi perilaku organisasi perusahaan; keempat, tanggungjawab filantropis dengan kata kunci "be a good citizen", dimana perusahaan dituntut agar dapat memberi kontribusi yang dapat dirasakan langsung oleh masyarakat.

Merujuk pada Saidi dan Abidin (2004 :6465) sedikitnya ada empat model atau pola CSR yang umumnya diterapkan oleh perusahaan di Indonesia: pertama, keterlibatan langsung. Perusahaan menjalankan program CSR secara langsung dengan menyelenggarakan sendiri kegiatan sosial atau menyerahkan sumbangan ke masyarakat tanpa perantara; kedua, melalui yayasan atau organisasi sosial perusahaan; ketiga, bermitra dengan pihak lain. Perusahaan menyelenggarakan CSR melalui kerjasama dengan lembaga sosial/organisasi non-pemerintah, instansi pemerintah, universitas atau media massa baik dalam mengelola dana maupun dalam melaksanakan kegiatan sosialnya, misalnya PMI, Yayasan Kesejahteraan Anak Indonesia, Dompet Dhuafa, instansi pemerintah (LIPI, Depdiknas, Depkes, Depsos), universitas (UI, ITB, IPB), media massa (Kompas, Kita Peduli Indosiar); keempat, mendukung atau bergabung dalam suatu konsorsium. Perusa- haan turut mendirikan, menjadi anggota atau mendukung suatu lembaga sosial yang didirikan untuk tujuan sosial tertentu, seperti PT. Inco, PT Freeport, PT HM. Sampurno dan lainlainnya. (Ambadar, J. 2002.)

Dari berbagai pengalaman program CSR di berbagai belahan dunia, kerjasama antara pemerintah, perusahaan dan masyarakat merupakan pilihan yang terbaik meskipun bukan merupakan panacea, obat ampuh untuk seluruh penyakit. Natural Resources Cluster dari Business Partners for Development mendefinisikan kerjasama tiga institusi sebagai voluntary collaboration to promote sustainable development based on an efficient allocation of complementary resources across business, civil society and government.

Model penyampaian (delivery) kebijakan telah menjadi perhatian utama pada analisis CSR. Seperti yang diamati oleh Kaufman (1991), implementasi CSR kini telah melibatkan sejumlah besar stakeholder sehingga tidak jarang memunculkan potensi konflik dan disfungsionalitas. Kondisi ini lebih disebabkan oleh kompleksitas permasalahan yang harus dihadapi pemerintahan modern serta perubahan "arsitektur" masyarakat modern itu sendiri yang memerlukan layanan kesejahteraan melalui kontribusi pemerintah, pasar, organisasi sukarela dan rumah tangga individual.

Kebijakan-kebijakan negara bersumber pada kenyataan bahwa kebijakan itu dirumuskan oleh apa yang oleh Easton disebut sebagai orang-orang yang memiliki wewenang dalam sistem politik, yakni tetua adat, eksekutif, legislator, hakim, administrator dan sebagainya. Mereka inilah yang menurut Easton merupakan orang-orang yang dalam kesehariannya terlibat dalam urusan politik dan dianggap oleh sebagian besar warga sebagai pihak yang bertanggungjawab atas urusan-urusan politik dan berhak mengambil tindakan tertentu sepanjang tindakan tersebut masih berada dalam batasbatas peran dan kewenangan mereka.

Penjelasan di atas membawa implikasi, bahwa: pertama, kebijakan negara lebih merupakan tindakan yang mengarah pada tujuan daripada perilaku atau tindakan yang serba acak dan kebetulan. Kedua, kebijakan pada hakekatnya terdiri atas tindakan-tindakan yang saling berkaitan dan berpola serta mengarah 
pada tujuan tertentu yang dilakukan oleh pejabat pemerintah dan bukan merupakan keputusan yang berdiri sendiri. Ketiga, kebijakan bersangkut paut dengan apa yang senyatanya dilakukan pemerintah dalam bidang tertentu. Keempat, kebijakan negara mungkin berbentuk positif, mungkin pula negatif. Dalam bentuknya yang positip, kebijakan negara mencakup beberapa bentuk tindakan pemerintah dengan cara mempengaruhi, sementara dalam bentuknya yang negatif, meliputi keputusan pejabat untuk tidak bertindak atau tidak melakukan tindakan apapun dalam masalah dimana campur tangan pemerintah justru diperlukan.

Sistem kebijakan menurut Abdul Wahab (2004) mengandung tiga elemen yang memiliki hubungan timbal balik, meliputi kebijakan negara itu sendiri, pelaku kebijakan dan lingkungan kebijakan. Kebijakan negara misalnya: kebijakan hak-hak sipil; kebijakan retribusi; kebijakan pendidikan; kebijakan pertanian dan lain sebagainya. Sementara sistem politik yang mempengaruhi pelaku kebijakan itu sendiri, misalnya: bentuk pemerintahan; birokrasi yang ada; tipe konstitusi dan sebagainya. Sedangkan kekuatan lingkungan yang berpengaruh disini dimaksudkan seperti misalnya sistem sosial ekonomi; arus urbanisasi; serta tingkat kesejahteraan dan lain sebagainya

Pada prinsipnya paradigma kebijakan publik merupakan sintesis antara ilmu politik dan ilmu organisasi. Howlett dan Ramesh (1995) secara gamblang menyatakan bahwa paradigma kebijakan publik memiliki perspektif organisatoris, politis dan pendekatan manajemen. Kebijakan publik adalah satu set keputusan saling berhubungan yang diambil oleh seorang aktor politisi atau kelompok aktor mengenai pemilihan tujuan dalam situasi tertentu di mana keputusan ini pada prinsipnya perlu.

Kebijakan publik bersifat aplikabel dan mencakup berbagai analisis kerangka organisasi yang diperlukan untuk memperoleh suatu pemahaman sosio-teknikal yang lebih dalam dan menyempurnakan solusi yang lebih baik. Mencoba untuk membawa ilmu pengetahuan dan teknologi modern dalam mendalami masalah masyarakat. Analisis kebijakan mencari-cari tindakan yang mungkin, mencari informasi dan menyusun bukti yang bermanfaat serta konse- kwensi yang mungkin timbul dalam kerangka membantu pembuat kebijaksanaan yang paling menguntungkan. Riset operasi, analisa sistem, cost-benefit adalah kategori yang sering dipakai. Di dalam analisa kebijakan menyiratkan penggunaan intuisi, penyesuaian-penyesuaian dan meliputi tidak hanya pengujian kebijakan dengan sintesis alternatif. Laswell (1971) memperjelas konsep kebijakan publik sebagai mengacu pada keputusan desain pemerintah dengan berbagai permasalahan sosialnya. Analisa Kebijakan membantu melukiskan tujuan, macam tindakan alternatif dan biaya-biaya jangka panjang maupun jangka pendek .

Perdebatan teoritik terhadap model pendekatan dan juga karakteristik yang dapat menjelaskan perubahan dan dampak perubahan yang terjadi dalam suatu kebijakan publik mengalami evolusi secara alamiah. Pendekatan yang berpusat pada masyarakat (society centered) berkesimpulan bahwa perubahan kebijakan dalam mekanisme analisis kebijakan selalu diwarnai dan muncul dari adanya peferensi dan hasil tekanan dari kelompok kepentingan di masyarakat. Sementara itu pada analisis yang berpusat pada negara (state centered) senantiasa berasumsi bahwa perubahan kebijakan publik timbul dari preferensi elit birokrasi dalam berbagai jenjangnya. Namun di negara berkembang seperti Indonesia kedua analisis kebijakan publik tersebut dapat dipakai untuk menjelaskan proses analisis kebijakan pemberdayaan petani dilihat dari sisi proses penetapan dan implementasinya.

Komponen lain yang tak kalah pentingnya dalam analisis kebijakan adalah strategi yang dipergunakan. Menurut Friedmann (1983), ada beberapa strategi yang dapat dipergunakan dalam proses pemberdayaan masyarakat, meliputi: strategi fasilitasi; strategi persuasi; strategi re-edukasi; strategi kekuasaan. Program pemberdayaan bertujuan meningkatkan kemampuan berusaha, baik dari aspek motivasi, teknologi, manajemen, permodalan maupun pemasarannya agar mampu mandiri serta memiliki posisi penawaran (bergainning position) yang kuat apabila berhadapan dengan aktor-aktor lain. Aksi pemberdayaan diharapkan menciptakan proses berkelanjutan melalui proses sebagai berikut: (1) proses konvergensi, dimana 
antaranggota kelompok melakukan reposisi dengan penggalangan sumberdaya, dengan demikian sektor kerakyatan dapat melepaskan diri dari posisi marjinalnya sehingga terjadi peningkatan ekonomi dan kesejahteraan masyarakat serta mengurangi kesenjangan; (2) proses sinergik antar pelaku pembangunan, yang berarti terjadi interaksi diantara komponen sistem yang menghasilkan keluaran yang lebih besar. Proses ini selanjutnya diharapkan menghasilkan kinerja sistem yang lebih baik; (3) proses sibernetik, yang berarti suatu sistem diharapkan dapat mengatur dirinya sendiri yang memungkinkan kelompok masyarakat bertumbuh dengan sendirinya atau swadaya.

Selain pendekatan yang berbasis pada masyarakat, antropolog Indonesia Kusnadi (2003) mencoba mengetengahkan model pendekatan institusional. Pendekatan institusional adalah pendekatan yang berbasis pada institusi (pranata) sosial budaya yang tumbuh, hidup dan berkembang dalam masyarakat yang bersangkutan. Secara antropologis, institusi merupakan sistem norma yang mengatur perilaku masyarakat untuk memenuhi kebutuhan tertentu dalam kehidupan mereka. Institusi merupakan media yang memperantarai perwujudan kebudayaan manusia. Keragaman pranata terbentuk sesuai dengan keragaman kehidupan masyarakat. Dengan demikian akan terdapat banyak jenis institusi, seperti institusi sosial, ekonomi dan budaya. Asumsi dasar menggunakan pendekatan institusional untuk kegiatan pemberdayaan masyarakat adalah bahwa suatu program pemberdayaan akan dapat berjalan dengan baik jika program tersebut dilaksanakan dalam kerangka institusi yang dimiliki masyarakat setempat. Institusi tersebut memiliki daya kohesif sosial yang tinggi dan menjadi tumpuan kehidupan masyarakat yang memilikinya.

Berbeda dengan pendekatan institusional, pendekatan Community Based Resources Management (CBRM) merupakan sosok manajemen pembangunan yang mencoba menjawab tantangan pembangunan, yaitu kemiskinan, memburuknya lingkungan hidup dan kurangnya partisipasi masyarakat di dalam proses pembangunan. CBRM merupakan mekanisme perencanaan yang menekankan pada teknologi "social learning" dan strategi perumusan program yang bertujuan untuk meningkatkan kemampuan masyarakat mengaktualisasikan diri. Pokok pikiran yang terkandung dalam CBRM adalah mencakup: pertama, keputusan dan inisiatif pemenuhan kebutuhan masyarakat setempat dibuata di tingkat lokal oleh warga masyarakat yang memiliki identitas yang diakui peranannya; kedua, memperkuat kemampuan masyarakat miskin mengarahkan dan mengatasi aset-aset yang ada untuk memenuhi kebutuhannya; ketiga, toleransi yang besar terhadap variasi dan karenanya mengakui makna pilihan nilai individual didalam pengambilan keputusan dan desentralisasi; keempat, CBRM menggunakan teknologi "social learning process" dimana individu berinteraksi satu sama lain menembus batas organisatoris dengan mengacu pada kesadaran kritis masing-masing; kelima, Budaya kelembagaan ditandai oleh adanya organisasi otonom, mandiri dan saling berinteraksi memberikan umpan balik; keenam, adanya jaringan koalisi dan komunikasi antara pelaku organisasi lokal yang otonom (Tjokrowinoto, 1996).

Senafas dengan metode CBRM, Chambers (1996) menawarkan sebuah konsep yang disebut PRA (Participatory Research Appraisal). Konsep ini pada awalnya telah diadopsi Ditjen Pembangunan Desa Departemen Dalam Negeri untuk dikembangkan menjadi metode perencanaan partisipatif. PRA merupakan suatu pendekatan dan metode mempelajari kondisi kehidupan masyarakat, yang meliputi analisis, perencanaan dan tindakan. Pendekatan PRA memungkinkan masyarakat desa saling berbagi, meningkatkan dan menganalisis pengetahuan mereka tentang kondisi kehidupan, membuat rencana sekaligus bertindak. PRA berfungsi sebagai upaya persiapan sosial (social preparing) sebelum aksi digulirkan (Sutrisno, 2003). Dengan pengertian bahwa kegiatan pembangunan dirancang, dilaksanakan, dikembangkan dan dimiliki oleh masyarakat, maka peran serta "orang luar", yakni aparat, konsultan dan agen perubahan hanya sebagai katalis dan masyarakat sebagai "klien". Dengan demikian masyarakat didampingi untuk memecahkan permasalahan mereka melalui hasil kerja mereka sendiri sehingga seluruh proses pembangunan meru- 
pakan proses belajar bagi tiap pihak yang terlibat kegiatan. Pendekatan partisipatif dengan pola PRA memiliki beberapa teknik tergantung fokus kegiatan, lokasi dan sasaran yang akan dicapai tetapi masih dalam misi yang sama, yaitu: partisipasi penilaian perdesaan (Participatory Rural Appraisa); Partisipasi Riset Dan Pengembangan (Participatory Research and Development); Partisipasi Penilaian Cepat (Participatory Rapid Appraisal); Partisipasi Teknologi Dan Pengembangan (Participatory Technologi and Development); partisipasi di bidang riset (Participatory Action Research); partisipasi mempelajari metode belajar (Participatory Learning Methode); partisipasi perencanaan dan pendugaan (Participatory Assesment and Planning) Pendekatan PRA memberikan manfaat pada kelancaran proses pelaksanaan program: tiap aktor yang terlibat dalam proses pembangunan sadar akan maksud dan tujuan dari suatu kegiatan yang mereka lakukan, saling belajar dari proses pembangunan itu sendiri, terjadinya proses konsentrasi potensi bukan oleh sebab mobilisasi tetapi oleh sebab tumbuhnya kesadaran dan tekad bersama untuk melakukan sesuatu yang telah mereka sepakati, dan tumbuhnya rasa solidaritas dan rasa memiliki.

Beberapa penelitian mengenai model CSR dalam memberdayakan petani telah peneliti telaah, seperti penelitian Sumaryo dari Fakultas Pertanain Unlam tahun 2008 tentang "Pemberdayaan Ekonomi Masyarakat dalam Implementasi CSR oleh PT.GGP di Kab.Lampung Tengah. Hasil penelitian menunjukan bahwa CSR dilakukan melalui kemitraan. Dengan kelompok peternak Kampung Karang Endah berupa budidaya penggemukan sapi potong, dengan Kampung Gunung Batin Udik berupa budidaya singkong, dan Kelompok ibu-ibu PKK kampung Terbanggi Besar berupa penjahitan pakaian kerja karyawan. Temuan lain dari riset tersebut adalah bahwa karakter individu target dan kualitas CSR ternyata tidak berpengaruh terhadap perubahan perilaku usaha, sedangkan kompetensi fasilitator dan faktor pendukung usaha berpengaruh nyata terhadap perubahan perilaku berusaha masyarakat. Sementara perilaku berusaha masyarakat berpengaruh nyata terhadap tingkat keberdayaan ekonomi masyarakat. Hasil telaah peneliti, model CSR tersebut hanya membawa pengaruh terhadap pendapatan masyarakat target, tetapi bersifat parsial, tidak terintegrasi secara holistik dari hulu hingga hilir sehingga diragukan keberlanjutannya.

Adapun penelitian yang pernah dilakukan peneliti di tahun 2009 tentang model CSR di dalam memberdayakan petani di desa Genting Kabupaten Semarang menunjukan bahwa pemberdayaan petani dilakukan dengan membuat kebun percontohan beberapa tanaman unggulan seperti durian montong, lengkeng itoh, jambu air, srikaya, melón, rambután, mangga dan buah naga. Kebun buah ini murni milik swasta dan dikelola secara profesional dibawah PT. Zansibar melalui proses riset dan development dikembangkan terus menerus dan hasilnya didesiminasikan. Selanjutnya petani desa Genting dijadikan kader, dibangunkan "embung", diberi saprotan dan pembekalan ilmu dengan muatan 80 persen praktek. Sebelum berproduksi lahan dikelola seperti perusahaan dimana kader diangkat sebagai karyawan dan digaji selama 3 tahun. Setelah usia produksi seluruh hak pengelolaan diberikan kepada petani. Dari hasil perhitungan peneliti, setelah tahun ke 3 petani akan memperoleh penghasilan 1 juta/bulan dan meningkat terus secara progresif seiring dengan penambahan usia produksi kurang lebih 25 tahun. Model CSR di atas memang juga dapat meningkatkan pendapatan petani, tetapi belum bersinergi dengan pelaku pembangunan lainnya sehingga kurang berdayaguna, khususnya sebagai kekuatan ekonomi regional.

Berdasarkan latar belakang masalah, kajian teoritis dan hasil penelitian terdahulu, terdapat persoalan tentang keberlanjutan program CSR dan ketidakholistikan program pemberdayaan petani. Untuk tujuan tersebut, maka diperlukan penelitian model kebijakan pemberdayaan petani melalui pengintegrasian program CSR . Model ini nantinya diharapkan dapat dijadikan model alternatif yang lebih efisien dan efektif karena seluruh sumberdaya yang tersedia dapat diintegrasikan dan dimanfaatkan secara optimal. 


\section{METODE PENELITIAN}

Penelitian menggunakan dua pendekatan sekaligus, yaitu pendekatan kualitatif (Bogdan \& Biklen, 1998) atau naturalistik (Lincoln \& Guba, 1985). Mengingat pendekatan yang digunakan, maka dalam mendeskripsikan fenomena tersebut peneliti menggunakan prosedur induktif, dimana manusia sebagai instrumen utamanya. Sementara metode kuantitatif dimaksudkan untuk menghitung reyturn on invesment, net revenue dan payback period.

Aspek-aspek yang diteliti adalah mekanisme pengintegrasian, institusi serta aktor yang terlibat, instrumen kepengaturan yang digunakan, pendekatan yang digunakan, dampak dan hambatan-hambatan di dalam proses pengintegrasian, serta tingkat efektivitasnya.

Lokasi penelitian ini mengambil tempat di wilayah Provinsi Jawa Tengah. Sedangkan situs penelitian Sentra Pemberdayaan Petani (SPT) desa Genting Ambarawa, desa Musuk kabupaten Boyolali, desa Sluke Kabupaten Rembang dan Bancak Kabupaten Semarang dan desa Seboro Kabupaten Kebumen. Data primer bersumber dari informan, yaitu petani, pemangku jabatan di masing-masing wilayah, pihak BUMN (Pertamina dan BPD). Sedangkan data sekunder bersumber dari dokumen-dokumen organisasi pelaksana maupun instansi yang terkait. Pemilihan informan dilakukan dengan teknik purposive sampling. Teknik ini digunakan dengan tujuan mengarahkan pengumpulan data agar sesuai dengan kebutuhan dan dilakukan dengan menyeleksi informan yang benar-benar menguasai informan serta permasalahan yang ada dan dapat dipercaya. Pengumpulan data menggunakan teknik: wawancara mendalam; observasi; Focus Group Discussion; kuesioner; dan studi dokumentasi. Sementara untuk mengukur tingkat efektivitasnya digunakan kuesioner dengan variabel modal yang diperlukan, biaya yang dikeluarkan dan hasil yang didapat.

Pada pendekatan kualitatif, data dianalisis dengan menggunakan model interaktif, sedangkan pada pendekatan kuantitatif dilakukan dengan menggunakan cost $\mathcal{E}$ benefit analisis. Analisis ini diperlukan tidak saja untuk kepentingan jangka pendek, yaitu "profit maximization" tetapi juga untuk kepentingan jangka panjang yaitu "wealth maximization".

\section{HASIL DAN PEMBAHASAN}

Pengintegrasian diawali dengan kunjungan Menteri Negara BUMN, Direktur Umum \& SDM Pertamina, Komisaris Utama PT. PLN dan Direktur PLN Jawa-Bali beserta staf dengan Pengurus Yayasan Obor Tani di Agrowisata Plantera, Kendal. Tujuan kunjungan Meneg BUMN bersama pimpinan Pertamina dan PLN sedang mencari Format CSR Pertanian. Pada saat itu, Ketua Yayasan Obor Tani memaparkan program Yayasan Obor Tani yang disebut SPT (Sentra Pemberdayaan Tani). Meneg BUMN dan para Pimpinan Pertamina, PLN dan BPD sangat tertarik dan kemudian bermaksud menyalurkan CSR nya untuk para petani melalui Yabortan secara bertahap dengan perincian Rp3,9 milyar untuk pembangunan Sentra Pemberdayaan Petani (SPT) desa-desa di Jawa Tengah. Empat SPT masing-masing terletak di Musuk Kabupten Boyolali, Sluke Kabupaten Rembang, Seboro Kabupaten Kebumen dan Bancak Kabupaten Semarang. Yabortan, Pertamina dan BPD bersinergi dengan Pemerintah Provinsi Jawa Tengah, dimana waduk mini dibangun Pemprov Jateng, sedangkan Kebun buah dan Pemberdayaan Petani oleh Pertamina. PLN siap mensponsori 2 SPT di dua desa di Jawa Barat dan 2 SPT untuk desa di Jawa Timur.

Sebagai pemangku kepentingan di tingkat provinsi, gubernur mengkoordinasikan program tersebut melalui kegiatan sosialisasi tentang pembangunan SPT, Waduk mini sekaligus penentuan lokasi Waduk Mini, sekaligus pendaftaran calon peserta program SPT bersama Biro Pembangunan Provinsi Jawa Tengah, Bakorluh Provinsi Jateng, Dinas PSDA Prov. Jateng, Perangkat Kabupaten, Kecamatan dan Kelurahan. Pemantapan sosialisasi calon peserta SPT dilakukan dengan kunjungan 300 peserta dari desa di Kabupaten Semarang, Boyolali dan Rembang, datang ke SPT Genting dan Agrowisata Plantera dalam beberapa gelombang untuk melihat bagaimana sebuah SPT dibangun, bagaimana SPT yang sudah berjalan. 
SPT berfungsi tidak saja sebagai supplay center (bibit, pupuk, dan obat-obatan), training center (petani berlatih, bertanya, dan melihat) tetapi juga research center (uji benih, pupuk, obatobatan, dan uji tanah)

Sebagai tindak lanjut dari komitmen Gubernur Jateng, maka 2 waduk mini di desa

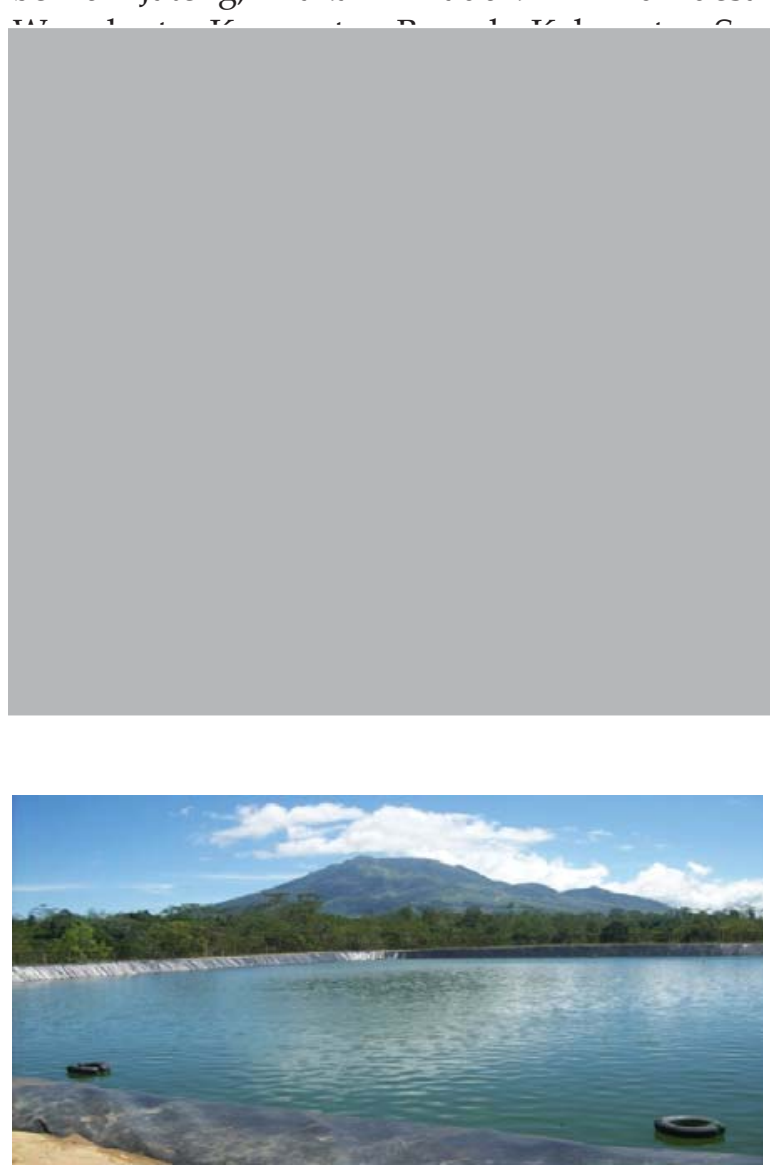

Sumber: Data diolah (2010)

\section{Gambar 1. Waduk Mini (embung) di SPT}

Selanjutnya untuk mencairkan dana, Asisten Manager CSR Pertamina dan Ast. Customer Relation Pertamina Regional IV Jateng-DIY mensurvei kembali 4 desa yang akan dibantu oleh Pertamina dan meninjau SPT yang sudah jadi di Desa Genting. Akhirnya surat persetujuan Dana CSR untuk 4 desa Sentra Pemberdayaan Tani, dikirimkan ditandatangani oleh Manager CSR Pertamina. Bantuan digulirkan dalam 3 Tahap: Tahap I, 2010: Rp1.421.800.000,-; Tahap II, 2011, Rp1.424.623.000,-; Tahap III, 2012, Rp1.116.968.700,-.
Proses pemberdayaan petani khususnya lahan kering telah melibatkan banyak institusi dan elemen masyarakat. Untuk itu dalam implementasinya memerlukan beberapa pendekatan. Pendekatan top down digunakan pemangku kepentingan wilayah melalui penetapan instrumen-instrumen kebijakan. Pendekatan

membangun embung percontohan dan kebun buah di Ngebruk Sukorejo Kabupaten Kendal. Melihat kesuksesan di Ngebruk, beberapa pengusaha menyalurkan dana CSR nya ke Genting yang memiliki potensi agrowisata. Hal ini jelas relevan dengan pendapat Schumpeter yang mengatakan kaum enterpreneurlah yang dapat menginduksi pertumbuhan ekonomi. Model pemberdayaan petani di desa Genting inilah yang kemudian diadopsi oleh pemerintah Jawa Tengah untuk mengintegrasikan penyaluran dana CSR BUMN di 4 lokasi kabupaten/kota.

Proses pemberdayaan petani khususnya hortikultura telah melibatkan banyak institusi dan elemen masyarakat. Untuk itu dalam implementasinya memerlukan beberapa pendekatan. Pendekatan top down digunakan pemangku kepentingan wilayah melalui penetapan instrumen-instrumen kebijakan. Pendekatan ini efektif dikarenakan pemerintah memiliki sumber-sumber bonus/sanksi serta berkemampuan memonopoli akses. Pendekatan persuasif dan reedukasi dipergunakan ketika masyarakat target mengetahui ada masalah dan membutuhkan perubahan. Pendekatan ini berupaya membawa setiap perubahan melalui kebiasaan 


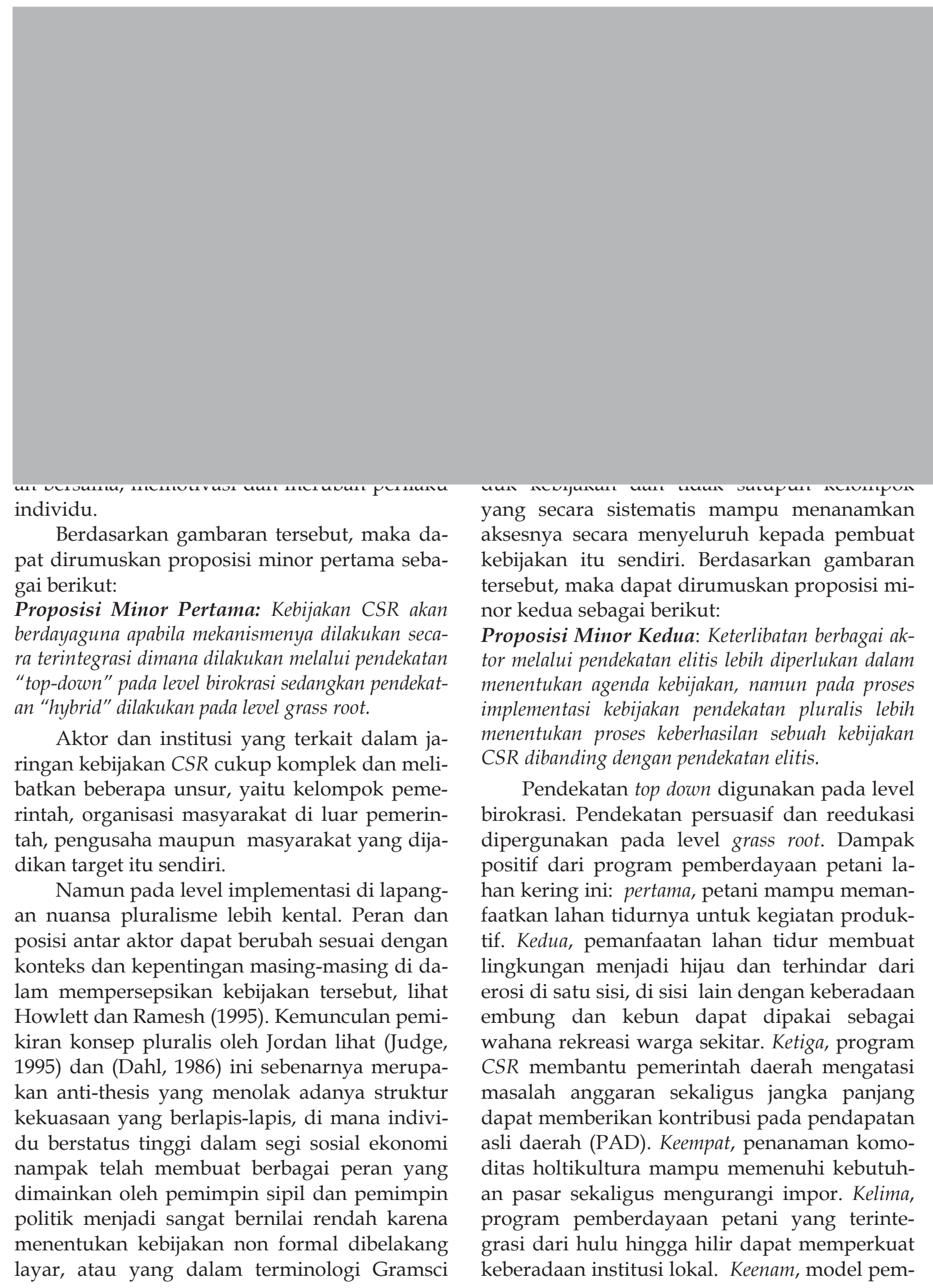


berdayaan petani lahan kering memberikan inspirasi bagi daerah lain yang memiliki kesamaan kontur tanah dan juga BUMN lain untuk menyalurkan sebagian dana CSR nya.

Hasil penelitian menunjukan bahwa jika keberadaan aktor-aktor melembaga dalam sebuah jejaring kebijakan maka akan dapat melengkapi keterbatasan pemda, tidak saja dalam memenuhi kebutuhan sumberdaya manusia dalam hal teknis konstruksi tetapi juga teknik pendekatan beserta finansialnya. Untuk itu berdasarkan hasil temuan pada kasus implementasi kebijakan CSR diatas dapat diajukan proposisi minor ketiga sebagai berikut

Proposisi Minor Ketiga: Keberadaan aktor yang melembaga dalam sebuah jaringan dan komunitas kebijakan menyebabkan proses pemberdayaan menjadi semakin kuat dan dapat secara efektif mempengaruhi model implementasi maupun pengembangan kebijakan CSR itu sendiri.

Implementasi penerapan model pemberdayaan petani tidak saja mempergunakan instrumen kepengaturan tetapi juga instrumen sumberdaya, baik sumberdaya manusia maupun sumberdaya finansial. Instrumen kepengaturan yang dipakai adalah: pertama, Undang-undang Nomor 40 Tahun 2007 tentang Perseroan Terbatas yang disahkan DPR tanggal 20 Juli 2007; kedua, Undang-undang No 32 tahun 2002 tentang Otonomi Daerah. Didalam pelaksanaannya kegiatan CSR juga mengacu pada standart ISO 26000 dimana memuat "practical ouidance" dengan komunitas; dan kelima, meningkatkan reputasi dan corporate building. Hal ini senada dengan pemikiran Doern dan Phidd (lihat Howlett \& Ramesh, 1995) yang mengatakan bahwa penggunaan instrumen campuran memungkinkan pemerintah untuk ikut campur sampai tingkatan tertentu didalam setiap keputusan yang diambil oleh berbagai aktor yang terlibat.

Untuk itu dalam penelitian ini dapat disusun proposisi sebagai berikut:

Proposisi Minor Keempat: Instrumen campuran diperlukan dalam mengimplementasikan kebijakan CSR, khususnya untuk mengakomodasi keragaman keuangan perusahaan, meningkatkan aksestabilitas masyarakat target serta mengantisipasi rendahnya kapasitas pemerintah dalam mempengaruhi para aktor.

Hal ini jelas tidak sejalan dengan pendapat Stepen Linder dan Guy Peters (lihat Howlett \& Ramesh, 1995) yang menyatakan bahwa apabila kapasitas pemerintah rendah sementara kompleksitas kebijakan subsistem tinggi maka instrumen voluntary dan community based instrument yang dipilih.

Namun demikian pembangunan dimanapun selalu memiliki ekses negatif. Ekses negatip muncul ketika hanya beberapa petani saja yang terpilih menjadi kader dan mendapatkan upah sebagai karyawan pemelihara tanaman (kapetan). Ekses negatip lain muncul ketika pembangunan embung di Bancak bobol karena 
yang akhir-akhir ini melanda Indonesia. Akibat dari kondisi alam tersebut pohon yang sudah dibungakan banyak yang rontok. Sementara pohon yang belum dibungakan akhirnya ditunda menunggu iklim normal kembali.

Di dalam proses implementasi kebijakan selalu akan terbuka kemungkinan terjadinya implementation gap, yaitu perbedaan antara yang diharapkan dan kenyataan yang dicapai. Banyak faktor yang mempengaruhi kesuksesan implementasi, baik itu bersifat internal maupun eksternal. Tidak terlaksananya program sesuai jadwal yang telah ditetapkan lebih berdomain politis dan kultural. Kultur birokrat yang selalu minta dilayani, job description yang tidak jelas, aparat berganti-ganti ketika harus berkoordinasi, pergantian pejabat PT Pertamina, sistem penganggaran yang konvensional menyebabkan kecepatan bergerak relatif lamban dan membuka peluang atas kebocoran-kebocoran dana. Hal ini tidak saja berdampak pada tertundanya jadwal tetapi sempat juga memunculkan sinisme dan apatisme warga.

Berkaitan dengan kompleksnya permasalahan yang terjadi, relevan juga dengan pendapat Morgan tentang kegagalan yang diakibatkan oleh metafora rantai komando yang buruk, kultur organisasi, serta pertahanan ego/insting. Kemajemukan kondisi sosial ekonomi masyarakat memang bukan merupakan masalah yang mudah. Karena kemajemukan tersebut mempengaruhi cara berpikir seseorang, baik pihak yang mengimplementasikan kebijakan maupun yang menjadi sasaran kebijakan. Keragaman inilah yang sering memicu pertentangan dan bahkan menjadi penghambat kebijakan CSR di satu sisi. Disisi lain kemajemukan cara berpikir dan kecepatan bertindak birokrasi pemerintahan dengan swasta ataupun organisasi di luar pemerintah amatlah berbeda. Birokrasi pemerintah menggunakan pendekatan top down dalam bertindak, dimana orang akan melaksanakan apa yang diminta dan diperintahkan atasan, tanpa reserve dan tanpa melalui proses kreatif. Jika implementasi kurang sempurna yakni tujuan tidak tercapai lebih disebabkan karena strategi yang keliru, mesin atau instrumen yang keliru ataupun operasionalisasinya yang buruk (lihat Sabatier \& Mazmanian, 1979).

Program pemberdayaan petani berarti pula memahami pembangunan pertanian sebagai perubahan struktur. Cara berpikir birokrat maupun petani sendiri harus diubah dari tindakan yang bersifat parsial menjadi program terintegrasi. Aksi tersebut diatas diharapkan menciptakan proses berkelanjutan melalui: pertama, proses konvergensi, dimana antaranggota kelompok melakukan reposisi dengan penggalangan sumberdaya, dengan demikian petani dapat melepaskan diri dari posisi marjinalnya sehingga terjadi peningkatan ekonomi dan kesejahteraan serta mengurangi kesenjangan; kedua, proses sinergik antar petani, yang berarti terjadi interaksi diantara komponen sistem yang menghasilkan keluaran yang lebih besar. Proses ini selanjutnya diharapkan menghasilkan kinerja sistem pengelolaan yang lebih baik; ketiga, proses sibernetik, yang berarti suatu sistem diharapkan dapat mengatur dirinya sendiri yang memungkinkan kelompok masyarakat bertumbuh dengan sendirinya atau swadaya.

Berdasarkan temuan di atas, maka dalam penelitian ini dapat diajukan proposisi minor sebagai berikut:

Proposisi Minor Kelima: Kemajemukan kondisi sosial ekonomi dan perbedaan kultur birokrasi meru-

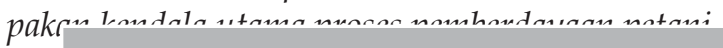

dar

pat

eko

revt

pro

keu

kels

hur

2.00

2.00

$\mathrm{Rp}]$

tun

pur

din

komoditas kelengkeng, durian, buah naga dan mangga memberikan keuntungan lebih besar dibanding bunga perbankan. Untuk tujuan efektivitas model produksi dilakukan melalui 
Tabel 2. Analisis B/C, ROI dan Payback Komoditas Hortikultura

\begin{tabular}{ccccc}
\hline \multirow{2}{*}{ Keterangan } & \multicolumn{4}{c}{ Jenis Komuditas (Rp) } \\
& $\begin{array}{c}\text { Kelengkeng } \\
\text { 4.000 pohon }\end{array}$ & $\begin{array}{c}\text { Naga } \\
\mathbf{4 0 . 0 0 0} \text { pohon }\end{array}$ & $\begin{array}{c}\text { 2.800 pohon } \\
\text { Durian }\end{array}$ & $\begin{array}{c}\mathbf{4 . 0 0 0} \text { pohon } \\
\text { Mangga }\end{array}$ \\
\hline Keuntungan & 600.000 .000 & 3.200 .000 .000 & 4.050 .000 .000 & 1.200 .000 .000 \\
Biaya & 1.752 .205 .000 & 1.824 .623 .000 & 1.116 .968 .700 & 1.421 .800 .000 \\
B/C & 0,34 & 1,75 & 3,62 & 0,337 \\
ROI & $34 \%$ & $175 \%$ & $362 \%$ & $33,7 \%$ \\
Payback Periode & 2,9 tahun & 0,5 tahun & 0,3 tahun & 2,9 tahun \\
\hline
\end{tabular}

Sumber: Data diolah (2010)

konsep "one product one village". Hal ini sesuai dengan teori David Korten tentang marketing mix dan David Ricardo tentang The Law of Deminishing Return", sehingga dengan bantuan teknologi marginal productivity dapat ditingkatkan. Pembangunan SPT disatu sisi telah memberikan tambahan pendapatan petani melalui pemenfaatan lahan tidurnya di sisi lain memberikan multiplier efek bagi tumbuh kembangnya sector agrowisata sekaligus menyerap tenaga kerja penduduk sekitar. Jangka panjang kondisi ini jelas memberikan kontribusi bagi pemerintah daerah berupa peningkatan pendapatan asli daerah (PAD)

Dari hasil dialog teoritis dapat diajukan proposisi minor berkaitan dengan tingkat efektivitas sebagai berikut:

Proposisi Minor Keenam: Pemberdayaan petani lahan kering efektif meningkatkan penghasilan petani sekaligus memberikan multiplier efek pada pendapatan masyarakat sekitar serta pemerintah daerah

Dengan memperhatikan seluruh pembahasan dan proposisi yang diajukan diatas, maka peneliti pada akhirnya menyusun proposisi mayor sebagai bagian utama temuan penelitian sebagai berikut:

Proposisi Mayor: Program CSR efektif apabila dilakukan terintegrasi melalui keterlibatan para aktor dan institusi dalam komunitas dan jaringan kebijakan dimana instrumen campuran menjadi sarananya serta community based organization sebagai pendekatannya.

\section{SIMPULAN}

Berdasarkan hasil penelitian dan pembahasan maka dapat ditarik kesimpulan sebagai berikut: pertama, pengintegrasian kebijakan CSR bagi pemberdayaan petani lahan kering dilakukan secara terstruktur dari provinsi hingga desa di bawah koordinasi Pemprop Jateng dengan pendampingan Yayasan Obor Tani sebagai konsultan teknis; kedua, institusi yang terlibat dalam program pemberdayaan meliputi BUMN, Pemerintah Provinsi, Pemerintah Daerah, Pemerintahan Desa, Swasta maupun masyarakat. Sementara aktor-aktor yang terlibat tidak saja dari kalangan birokrat tetapi pengusaha, intelektual perguruan tinggi serta masyarakat target; ketiga, instrumen-instrumen yang digunakan meliputi instrumen finansial bersumber dari dana CSR, APBD serta donatur swasta; instrumen kepengaturan dan instrumen sumberdaya manusia, sumberdaya alam serta sumberdaya sosial.; keempat, koordinasi dilakukan melalui pendekatan bottom-up pada level grass root dan top-down pada level birokrasi, sedangkan strategi yang digunakan adalah community development. Adapun dampak positif jangka pendek yang ditimbulkan adalah program lebih berdaya guna, jangka panjang program lebih berkesinambungan karena terjadi penguatan institusi lokal, mengurangi arus urbanisasi serta dimungkinkan dapat memberikan kontribusi bagi PAD. Sedangkan dampak negatifnya adalah terjadinya kecemburuan petani yang tidak terlibat dalam program; kelima, kendala eksternal yang terjadi bersumber dari perbedaan kultur organisasi pemerintah dan swasta, kecepatan geraknya, serta keberadaan cuaca ekstrem. Sedangkan kendala internal bersumber dari tingkat pengetahuan petani, keterbatasan akses informasi serta keberadaan institusi lokal itu sendiri; keenam, biaya pembuatan embung secara swakelola lebih ringan dibanding mela- 


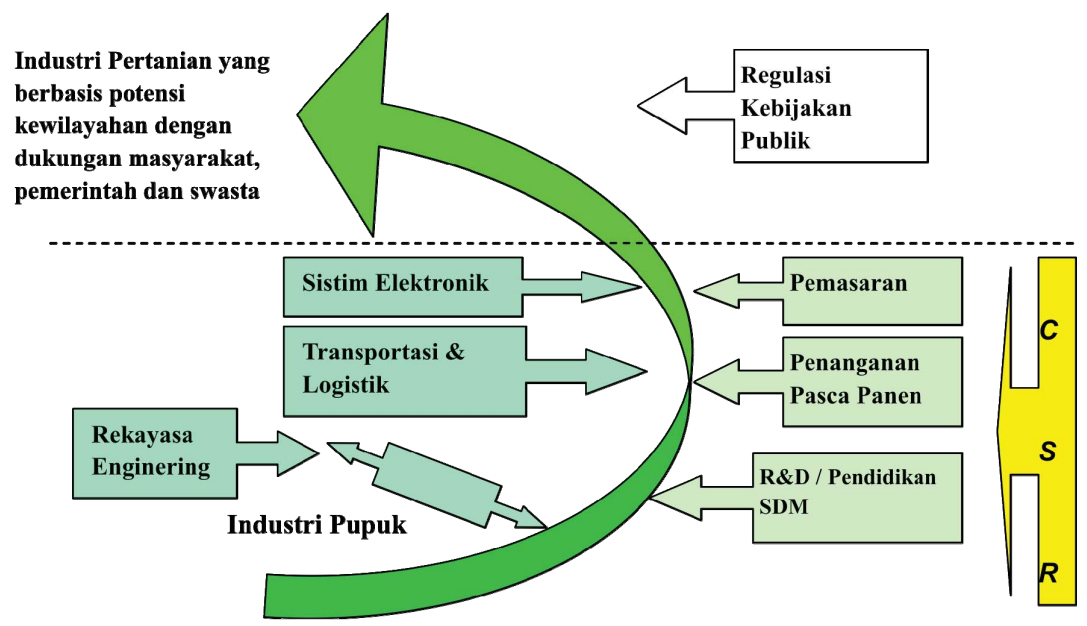

Sumber: Data diolah (2010)

Gambar 2. Model Pemberdayaan Petani Hortikultura Melalui Integrasi Program CSR

lui mekanisme tender. Hasil perhitungan Return on Invesment menunjukan bahwa penanaman komuditas holtikultura lebih menguntungkan dibanding tingkat bunga bank serta memberikan multiplier efek yang besar pada lingkungannya.

Sementara dengan memperhatikan kekuatan, kelemahan, peluang serta tantangan yang ada, maka dapat direkomendasikan hal-hal sebagai berikut: pertama, program pemberdayaan petani sebaiknya dilakukan terintegrasi tidak saja berkenaan dengan aspek finansial tetapi juga aspek riset dan pengembangan serta aspek penanganan pasca produksi. Pengintegrasian dilakukan lintas departemen/dinas di bawah koordinasi kepala daerah; kedua, komoditas tanaman yang akan dikembangkan hendaknya bervariasi tidak saja tanaman holtikultura dan tanaman pangan tetapi juga tanaman industri disesuaikan dengan kecocokan unsur agroklimat serta potensi kewilayahan dengan mengembangkan konsep "one product one village". Konsep ini memudahkan penanganan hama penyakit serta pemasaran hasil. Pengembangan komoditas harus diserta kegiatan riset secara terus menerus agar diperoleh kualitas unggul; ketiga, agar program berdayaguna dan memiliki kesinambungan, petani tidak saja diberi kail tetapi harus diajarkan bagaimana mengail yang baik sekaligus menyajikannya; keempat, pemanfaatan dana CSR sebaiknya langsung diswakelolakan agar efisien baik ditinjau dari segi biaya dan waktu.

Adapun model pemberdayaan petani hortikultura yang dapat direkomendasikan pada Gambar 2.

\section{DAFTAR PUSTAKA}

Abdul Wahab, S. 2001. Evaluasi Kebijakan Publik. Penerbit Bersama FIA Universitas Brawijaya dan Universitas Negeri Malang, Malang

Ambadar, J. 2002. Corporate Social Responsibility dalam Praktek di Indonesia. Jakarta: PT. Elex Media Komputindo.

Asongu,J.J. The History of Corporate Social Responsibility http://www6.miami.edu /ethics/pdf files/csr guide.pdf.

Barnett, Tim. "Corporate Social Responsibility". http://www.referenceforbusiness.com/C omp-De/Corporate-Social Responsibility. html

Bogasari. www.bogasari.com

Bogdan, R.C. \& Biklen. 1998. Qualitative Research for Education: an Introduction to Theory and Methods. London: Allyn and Bacon. 
Bryson, John. M. 1995. Strategic Planning for Public and Non Profit Organization: A guide to Strengthening and Sustaining Organizational Achievement. San Fransisco: Jossey Bass Publisher.

Budimanta A, Adi Prasetiko. 2005. Corporate Social Responsibility: Jawaban bagi Model Pembangunan Indonesia Masa Kini. Jakarta: Indonesia Center for Sustainable Development.

Cahyono, I. 2006. Politik Etis Kapitalisme. Kompas. 26 Oktober

Chambers, R. 1983. Rural Development Putting the Last First. London: Longman Inc.

De Soto, H. 2006. The Mystery of Capital. Pandu Aditya K (Penterjemah). Rahasia Kejayaan Kapitalisme Barat. Jakarta: Qalam

Friedman M. 1970. Social Responsibility of Business is to Increase its Profit. The New York Time Magazine, 13 September.

Gramsci, A. 1976. Selection From The Prison Notebooks. New York: Quintin Hoare dan Nowell Smith (ed) International Publisher.

Howlett, M and Rames M. 1995. Studying Public Policy, Policy Cycless \& Policy Subsystems. Toronto: Oxford University Press.

Kaufman, S. 1991. Decision Making and Conflict Management Processes in Local Government. In Bingham et al

Korten, Frances. 1985. Community Participation a Management Perspectives on Obstacles Anoptian Bureaucracy and The Poor: Closing the Gap (David Korten and Flipo B Alfonso (eds.) the Asian Institute of Management, Manila, 2nd Printing.

Kottler, Phillip \& Lee, nancy. 2005. Corporate Social Responsibility. Doing the Most Good for Your Company and Your Cause. New Jersey: John Wiley \& Sons.

Laswell, HD. 1971. A Preview of Policy Sciences. New York: American Elsevier.
Lincoln, Y \& Guba, E. 1985. Naturalistic Inquiry. California: SAGE, Publications, Inc.

Mubyarto. 1991. Pengantar Ekonomi Pertanian. Jakarta: LP3ES.

Nuryana, Mu'man. 2005. Corporate Sosial Responsibility dan Kontribusi bagi Pembangunan Berkelanjutan, makalah disampaikan pada Diklat Pekerjaan Sosial Industri, Balai Besar Pendidikan dan Pelatihan Kesejahteraan Sosial (BBPPKS) Bandung, Lembang 5 Desember.

Parsons, W. 1995. Public Policy: An Introduction to The Theory and Practice of Policy Analysis. USA: Edward Elgar Publishing, Inc.

Porter, Michael E. Dan Mark R.Kramer. 2002. The Competitive Advantage of Corporate Philantropy dalam Harvard Business Review, December, hal 5.

Saidi, Zaim dan Hamid Abidin. 2004. Menjadi Bangsa Pemurah: Wacana dan Praktek Kedermawanan Sosial di Indonesia. Jakarta: Piramedia.

Schermerhorn, John. 2005. Management. New York: John Wiley \& Sons, Inc. (http:// www.personal.psu.edu/kez5001/CSR.htm)

Soekartawi. 2002. Prinsip Dasar ekonomi Pertanian: Teori dan Aplikasi. Jakarta: PT.Raja Grafindo Persada.

Suruji A. Ardhian Novianto. 2006. Bisnis dan Corporate Philanthropy. Kompas, 20 Mei

Suryana, 2000. Ekonomi Pembangunan: Problematik dan Pendekatan. Jakarta: Salemba Empat

Syafrani, Andi. CSR dalam Prespektif Corporate Law: Sebuah Upaya Pemetaan Anatomi Teoritis. http://www.legalitas. org/)

Wahyudi, Isa \& Azheri, Busyra. 2008. Corporate Social Responsibility: Prinsip, Pengaturan dan Implementasi. Malang: In-Trans Publishing. 